\title{
Aorto-Right Ventricular Tunnel in Transposition of the Great Arteries
}

\section{OPEN ACCESS}

Edited by:

Umberto Morbiducci, Politecnico di Torino, Italy

Reviewed by:

Luca Deorsola,

Ospedale Regina Margherita, Italy Alejandro José Lopez-Magallon, Children's National Health System, United States

${ }^{*}$ Correspondence: Antonio F. Corno afc10@/eicester.ac.uk

Specialty section: This article was submitted to Pediatric Cardiology, a section of the journal Frontiers in Pediatrics

Received: 04 December 2017 Accepted: 02 February 2018 Published: 21 February 2018

Citation:

Corno AF, Durairaj $S$ and Anderson RH (2018) Aorto-Right Ventricular Tunnel in Transposition of the Great Arteries.

Front. Pediatr. 6:30. doi: 10.3389/fped.2018.00030

\begin{abstract}
Antonio F. Corno ${ }^{1,2 *}$, Saravanan Durairaj ${ }^{2}$ and Robert H. Anderson ${ }^{3}$
${ }^{1}$ Cardiovascular Research Center, University of Leicester, Leicester, United Kingdom, ${ }^{2}$ East Midlands Congenital Heart Center, University Hospitals of Leicester, Glenfield Hospital, Leicester, United Kingdom, ${ }^{3}$ Institute of Genetic Medicine, International Centre for Life, Newcastle University, Newcastle upon Tyne, United Kingdom
\end{abstract}

Aorto-ventricular tunnel is an extremely rare congenital heart defect, consisting of failure of attachment of an aortic leaflet along the semilunar hinge. In all published reports the leaflet involved was either the right coronary leaflet, most frequently, or the left coronary leaflet, in most of the cases opening toward the left ventricle, with only one-eighth of the reported cases communicating with the right ventricle. Treatment of the aorto-ventricular tunnel has been anecdotally reported by interventional closure with a device and more frequently with surgical approach, either as an isolated malformation or as associated lesions. To the best of our knowledge, the presence of an aorto-ventricular tunnel of the non-adjacent aortic leaflet in transposition of the great arteries has never been reported. We have observed an aorto-ventricular tunnel involving the non-adjacent leaflet of the aortic root, which after arterial switch became the pulmonary root. The patient presented 18 years after the arterial switch with progressive dilatation of the right ventricle due to severe degree of pulmonary valve regurgitation, confirmed by echocardiography and cardiac MRI. Indication for surgery was given with the plan for a pulmonary valve implantation. Because of the intra-operative finding of disconnection of the anterior leaflet of the pulmonary valve (former aortic valve) along the semilunar hinge, the surgical plan was modified and the anterior leaflet was attached to the valve annulus, with subsequent plasty in correspondence with the right and left commissurae to reduce the size of the dilated annulus to normal diameter. The post-operative course was uneventful, with extubation after few hours and discharge 4 days after surgery, with echocardiography showing trivial degree of pulmonary valve regurgitation. The patient remains in good conditions 6 months after surgery.

Keywords: annular hinge, aorto-ventricular tunnel, arterial switch, new pulmonary valve regurgitation, semilunar valves

\section{INTRODUCTION}

Aorto-ventricular tunnel is an extremely rare congenital heart defect (1-25), consisting of failure of attachment of an aortic leaflet along the semilunar hinge $(24,25)$. In all published reports, the leaflet involved was either the right coronary leaflet, most frequently, or the left coronary leaflet (1-25), in most of the cases opening toward the left ventricle, with only one-eighth of the reported cases communicating with the right ventricle $(24,25)$. Treatment of the aorto-ventricular tunnel has been anecdotally reported by interventional closure with a device (26) and more frequently with surgical approach, either as an isolated malformation (27-62) or with associated lesions (63-70). 
To the best of our knowledge, the presence of an aortoventricular tunnel of the non-adjacent aortic leaflet in transposition of the great arteries has never been reported. We have observed an aorto-ventricular tunnel involving the non-adjacent leaflet of the aortic root, which after arterial switch became the pulmonary root.

\section{BACKGROUND}

Because of severe cyanosis in the presence of transposition of the great arteries and ventricular septal defect, a neonate underwent emergency balloon atrio-septostomy procedure at the age of 2 weeks. After few days, arterial switch and closure of ventricular septal defect were performed with uneventful post-operative course. The child was then followed with regular follow-up visits; at the age of 3 years, a follow-up cardiac catheterization showed normal reimplanted coronary arteries. From the age of 1 year, the echocardiography reports noted the presence of moderate degree of pulmonary valve regurgitation, increasing to severe degree around the age of 9 years, with the patient remaining asymptomatic. Since after, the echocardiographic investigations showed a progressive dilatation of the right ventricle, confirmed by MRI at the age of 17 years, showing an indexed end-diastolic right ventricular volume $=211 \mathrm{ml} / \mathrm{m}^{2}$.

At the 18 years of age, $64 \mathrm{~kg}$ of body weight, he presented with mild right ventricular impulse on the chest on examination, and systo-diastolic murmur compatible with free pulmonary valve regurgitation. Electrocardiography showed sinus rhythm with 53' heart rate, partial right bundle branch block with QRS duration $=110 \mathrm{~ms}$. Echocardiography showed severe pulmonary valve regurgitation, with Doppler velocity $=2.7 \mathrm{~m} / \mathrm{s}$ through the pulmonary valve.

Cardiac MRI confirmed the presence of severe pulmonary valve regurgitation with fraction of regurgitation $=57 \%$, dilated pulmonary valve annulus $(23 \mathrm{~mm}$, with $18.5 \mathrm{~mm}$ normal for the body surface area) (Figures 1A,B), severe dilatation of the right ventricle (Figure 1C), with ejection fraction $=50 \%$, indexed end-diastolic right ventricular volume $=226 \mathrm{ml} / \mathrm{m}^{2}$, indexed endsystolic right ventricular volume $=113 \mathrm{ml} / \mathrm{m}^{2}$, normal size and function of the left ventricle (Figure 1C). CT scan confirmed the findings, showing mildly dilated ascending neo-aorta and normal coronary arteries.

Cardiopulmonary stress test showed peak VO2 $=39 \mathrm{ml} / \mathrm{kg} /$ min ( $91 \%$ of normal), and peak heart rate $157^{\prime}$ ( $78 \%$ of normal). The test was terminated before reaching the maximum heart rate because of ST depression in V3 and V4, without chest pain.

At the multi-disciplinary meeting, the decision was agreed to proceed with pulmonary valve implantation, because of the severe degree of pulmonary valve regurgitation and right ventricular dilatation. The patient was informed and consent was given for the planned surgical procedure.

On general anesthesia, transesophageal echocardiography confirmed the presence of severe regurgitation of the pulmonary valve. The cardiopulmonary bypass, established between the left femoral artery and the right atrium, was maintained through the entire procedure on normothermia with beating heart. Through a longitudinal incision of the main pulmonary artery, in anterior position after the previous Lecompte maneuver, the presence of three leaflets pulmonary valve (native aortic valve) was confirmed, but while the two posterior leaflets appeared absolutely normal, the anterior non-adjacent leaflet was completely disconnected from the annulus and floating inside the pulmonary artery (Figure 2A). The disconnected anterior non-adjacent leaflet was reattached to the annulus with double running suture of 5/0 monofilament (Figure 2B). At this point, the pulmonary valve annulus, dilated to $24 \mathrm{~mm}$ diameter, was reduced to $19 \mathrm{~mm}$ diameter (normal for the age $=18.5 \mathrm{~mm}$ ) with plasty in correspondence of the right and left commissurae with 5/0 monofilament suture pledgeted with a small patch of autologous pericardium. After closure of the incision of the main pulmonary artery with double running suture of 5/0 monofilament, the patient was easily weaned from cardiopulmonary bypass after $35 \mathrm{~min}$, without inotropic support.
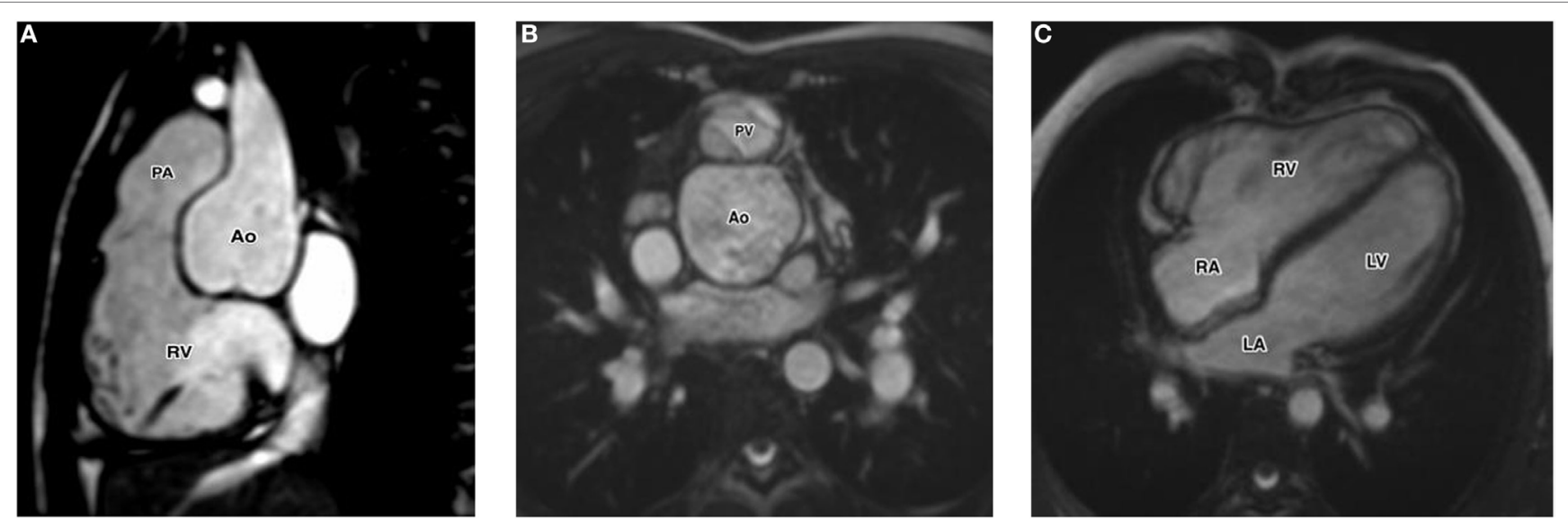

FIGURE 1 | (A) Cardiac MRI with sagittal view of the right ventricular outflow tract showing the anterior leaflet of the pulmonary valve without attachment to the annular hinge. (B) Cardiac MRI with axial view of the pulmonary valve showing morphologic abnormality of the anterior leaflet. (C) Cardiac MRI with four-chamber views showing the dilatation of the right ventricle. Abbreviation: LA, left atrium; LV, left ventricle; RA, right atrium; RV, right ventricle. 

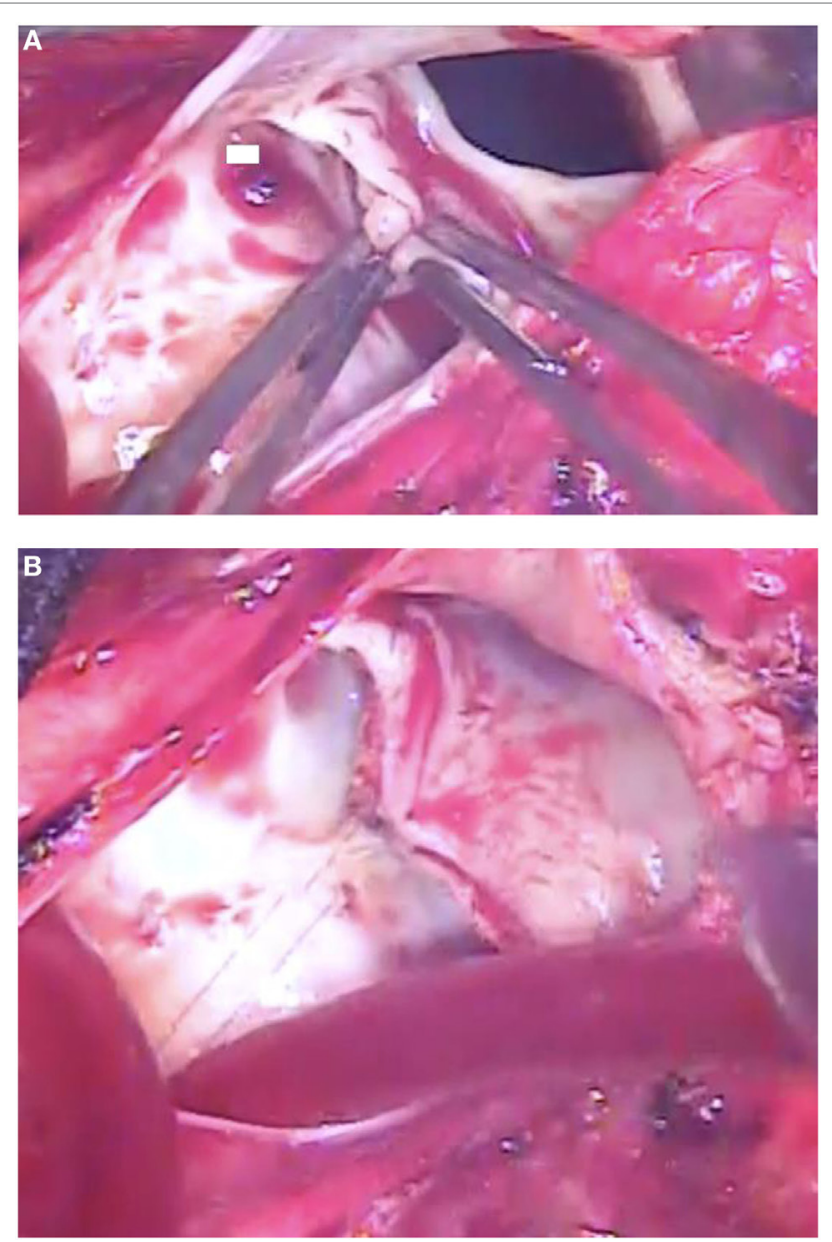

FIGURE 2 | (A) Intra-operative photograph showing the anterior leaflet of the pulmonary valve without any attachment to the annular hinge, while the other two leaflets are controlled with forceps. (B) Intra-operative photograph showing the anterior leaflet of the pulmonary valve reattached to the annulus with running suture.

Intra-operative transesophageal echocardiography confirmed the good result with trivial regurgitation of the pulmonary valve (Figure 3A). The rest of the hospitalization was uneventful, with extubation after few hours, discharge from ICU next morning and discharge home on the fourth post-operative day. Echocardiography before discharge confirmed the presence of well functioning pulmonary valve and reduced the size of the right ventricle (Figures 3B,C). The patient remains asymptomatic 6 months after surgery.

\section{DISCUSSION}

In all published reports of aorto-ventricular tunnel, extremely rare congenital heart defect, the leaflet involved was either the right coronary leaflet, most frequently, or the left coronary leaflet, but never the anterior non-adjacent leaflet (1-25).

We are not aware of any report, an aorto-ventricular tunnel of the non-adjacent aortic leaflet in transposition of the great arteries, with, therefore, aorto-right ventricular tunnel.
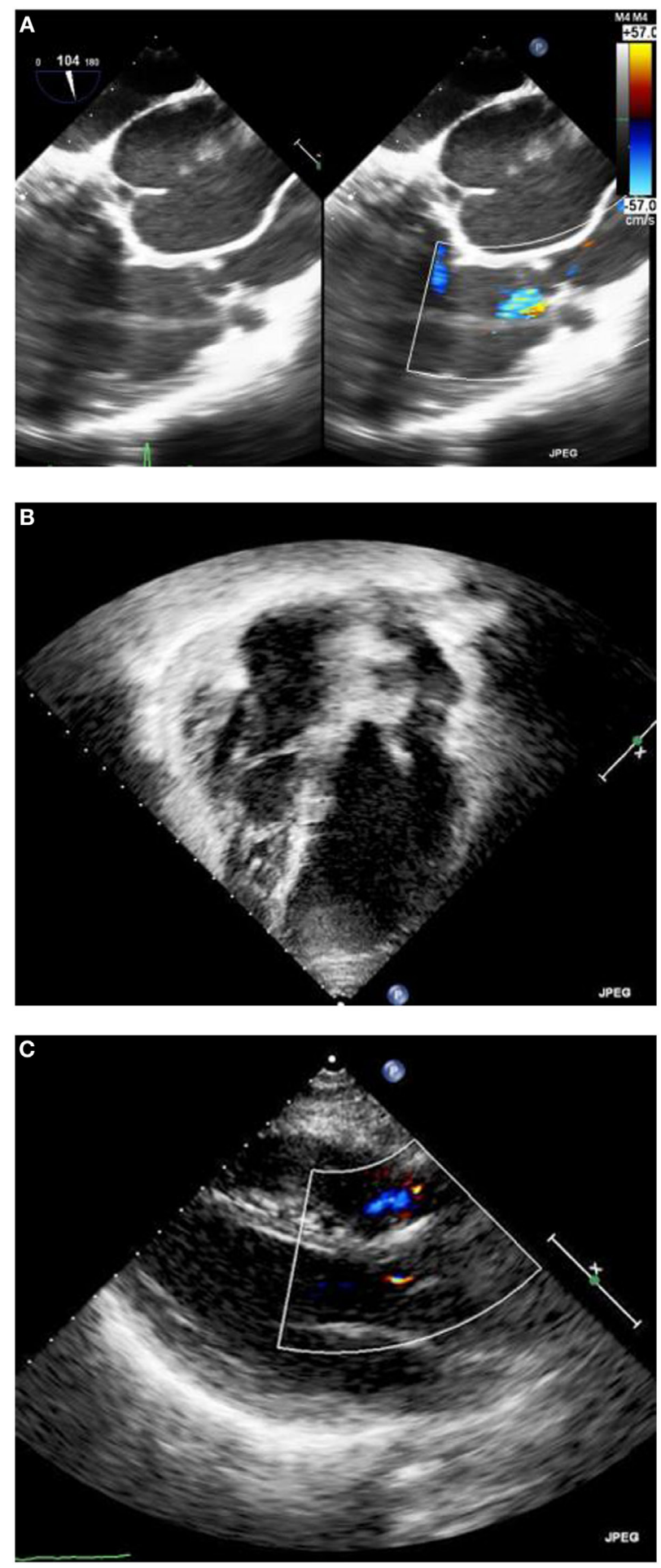

FIGURE 3 | (A) Intra-operative transesophageal echocardiography after repair, showing trivial residual degree of pulmonary valve regurgitation.

(B) Pre-discharge trans-thoracic echocardiography with the four chamber views.

(C) Pre-discharge trans-thoracic echocardiography with the long-axis view.

The patient we report underwent arterial switch in the neonatal period, but at that time no one observed the presence of native aortic valve regurgitation in the right ventricle, while regular 
reports have been done on the presence of pulmonary (previous aortic) valve regurgitation from the age of 1 year.

We tried to review all investigations available from the neonatal period, and we found an echocardiography recorded before the arterial switch, showing some evidence of native aortic valve regurgitation, but the quality of the imaging was too poor for printing.

Based on this observation, and on the intra-operative findings, we can assume that our patient presented with aorto-right ventricular tunnel in transposition of the great arteries. Evidently, the degree of aortic valve regurgitation at that time was only mild and the attention has been given only to the management of transposition of the great arteries with ventricular septal defect. Over the time, the regurgitation of the new pulmonary valve progressively increased, with subsequent dilatation of the right ventricle, to the point of requiring surgery because of excessive end-diastolic and endsystolic right ventricular volume. And after having found the morphology described, the plan of implanting a pulmonary valve has been changed to the repair of the disconnected nonadjacent leaflet.

\section{REFERENCES}

1. Corno AF. Aorto-left ventricular tunnel. In: Corno AF, editor. Congenital Heart Defects. Decision Making for Surgery. Volume 2. Less Common Defects. Darmstadt: Steinkopff Verlag (2004). p. 221-8.

2. Edwards JE, Burchell HB. The pathological anatomy of deficiences between the aortic root and the heart, including aortic sinus aneurysms. Thorax (1957) 12:125-39. doi:10.1136/thx.12.2.125

3. Levy MJ, Lillehei CW, Anderson RC, Amplatz K, Edwards JE. Aortico-left ventricular tunnel. Circulation (1963) 27:841-53. doi:10.1161/01.CIR.27.4.841

4. Cooley RN, Harris LC, Rodin AE. Abnormal communication between the aorta and left ventricle: aortico-left ventricular tunnel. Circulation (1965) 31:564. doi:10.1161/01.CIR.31.4.564

5. Roberts WC, Morrow AG. Aortico-left ventricular tunnel: a cause of massive aortic regurgitation and of intracardiac aneurysm. Am J Med (1965) 39:662-7. doi:10.1016/0002-9343(65)90087-2

6. Soulie P, Caramanian M, Pernot JM, Pauly-Laubry C. Left aorto-ventricular communication or tunnel. Arch Mal Coeur Vaiss (1966) 59:820-42.

7. Bove KE, Schwartz DC. Aortico-left ventricular tunnel: a new concept. Am J Cardiol (1967) 19:696-709. doi:10.1016/0002-9149(67)90475-4

8. Bharati S, Lev M, Cassels DE. Aortico-right ventricular tunnel. Chest (1973) 63:198-202. doi:10.1378/chest.63.2.198

9. Pérez-Martinez V, Quero M, Castro C, Moreno F, Brito JM, Merino G. Aorticoleft ventricular tunnel: a clinical and pathologic review of this uncommon entity. Am Heart J (1973) 85:237-45. doi:10.1016/0002-8703(73)90465-1

10. Saylam A, Tuncali T, Ikizler C, Aytac A. Aorto-right ventricular tunnel: a new concept in congenital cardiac malformations. Ann Thorac Surg (1974) 18:634-7. doi:10.1016/S0003-4975(10)64412-8

11. Norwicki ER, Aberdeen E, Friedman S, Rashkind WJ. Congenital left aortic sinus-left ventricle fistula and review of aortocardiac fistulas. Ann Thorac Surg (1977) 23:378-88. doi:10.1016/S0003-4975(10)64149-5

12. Sung CS, Leachman RD, Zerpa F, Angelini P, Lufschanowski R. Aortico-left ventricular tunnel. Am Heart J (1979) 98:87-93. doi:10.1016/0002-8703(79) 90324-7

13. Perry JC, Nanda NC, Kicks DG, Harris JP. Two-dimensional echocardiographic identification of aortico-left ventricular tunnel. Am J Cardiol (1983) 52:913-4. doi:10.1016/0002-9149(83)90443-5

14. Fripp RR, Werner JC, Whitman V, Nordenberg A, Waldhausen JA. Pulsed Doppler and two-dimensional echocardiographic findings in aortico-left ventricular tunnel. J Am Coll Cardiol (1984) 4:1012. doi:10.1016/ S0735-1097(84)80064-9

15. Bash SE, Huhta JC, Nihill MR, Vargo TA, Hallman GL. Aortico-left ventricular tunnel with ventricular septal defect: two dimensional/Doppler

\section{CONCLUDING REMARKS}

A very unusual combination of aorto-ventricular tunnel with transposition of the great arteries came to observation 18 years after the arterial switch performed in the neonatal period, due to progressive regurgitation of the native aortic valve in pulmonary position. Surgical repair of the lesion with attachment of the non-adjacent leaflet to the annulus avoided the planned valve implantation.

\section{ETHICS STATEMENT}

Written and informed consent was obtained from the patient for publication of this case report.

\section{AUTHOR CONTRIBUTIONS}

AFC proposed the report of this malformation never observed before, prepared the entire manuscript, and the revised edition. $\mathrm{SD}$ contributed to the preparation of the manuscript and the choice of the illustrations. RA revised and edited the manuscript after contributing to the literature review.

echocardiographic diagnosis. J Am Coll Cardiol (1985) 5:757-60. doi:10.1016/ S0735-1097(85)80408-3

16. Grant P, Abrams LD, De Giovanni JV, Shah KJ, Silove E. Aortico-left ventricular tunnel arising from the left ventricular sinus. Am J Cardiol (1985) 55:1657-8. doi:10.1016/0002-9149(85)91001-X

17. Humes RA, Hagler DJ, Julsrud PR, Levy JM, Feldt RH, Schaff HV. Aortico-left ventricular tunnel: diagnosis based on two-dimensional echocardiography, color flow Doppler imaging, and magnetic resonance imaging. Mayo Clin Proc (1986) 61:901-7. doi:10.1016/S0025-6196(12)62613-5

18. Tuna IC, Edwards JE. Aortico-left ventricular tunnel and aortic insufficiency. Ann Thorac Surg (1988) 45:5-6. doi:10.1016/S0003-4975(10)62383-1

19. Kafka H, Chan KL, Leach AJ. Asymptomatic aortico-left ventricular tunnel in adulthood.AmJ Cardiol(1989) 63:1021-2. doi:10.1016/0002-9149(89)90168-9

20. Kakadekar AP, Sandor GGS, Patterson MW, LeBlanc JG. Role of transesophageal echocardiography in the management of aortic-left ventricular tunnel. Pediatr Cardiol (1995) 16:137-40. doi:10.1007/BF00801913

21. Ho SY, Muriago M, Cook AC, Thiene G, Anderson RH. Surgical anatomy of aorto-left ventricular tunnel. Ann Thorac Surg (1998) 65:509-14. doi:10.1016/ S0003-4975(97)01083-7

22. Talwar S, Choudhary UK, Kothari SS, Airan B. Aortico-right ventricular tunnel. Int J Cardiol (1999) 31:201-5. doi:10.1016/S0167-5273(99)00059-5

23. Grab D, Paulus WE, Terinde R, Lang D. Prenatal diagnosis of an aortico-left ventricular tunnel. Ultrasound Obstet Gynecol (2000) 15:435-8. doi:10.1046/j.1469-0705.2000.00119.x

24. McKay R, Anderson RH, Cook AC. The aorto-ventricular tunnels. Cardiol Young (2002) 12:563-80. doi:10.1017/S1047951102001038

25. Anderson RH, Cook AC, Brown NA, Henderson DJ, Chaudhry B, Mohun T. Development of the outflow tracts with reference to aortopulmonary window and aortoventricular tunnels. Cardiol Young (2010) 20(Suppl3):92-9. doi:10.1017/S1047951110001137

26. Chessa M, Chaudhari M, De Giovanni JV. Aorto-left ventricular tunnel: transcatheter closure using an Amplatzer duct occluder device. Am J Cardiol (2000) 86:253-4. doi:10.1016/S0002-9149(00)00873-0

27. Bernhard WF, Plauth W, Fyler D. Unusual abnormalities of the aortic root or valve necessitating surgical correction in early childhood. N Engl J Med (1970) 282:68-71. doi:10.1056/NEJM197001082820204

28. Somerville J, English T, Ross DN. Aorto-left ventricular tunnel: clinical features and surgical management. Br Heart J (1974) 36:321-8. doi:10.1136/ hrt.36.4.321

29. Mair DD, Fulton RE, McGoon DC. Successful surgical repair of aortico-left ventricular tunnel in an infant. Mayo Clin Proc (1975) 50:691-6.

30. Edwards JE. Aortico-left ventricular tunnel: the case for early treatment. Chest (1976) 70:5-6. doi:10.1378/chest.70.1.5 
31. Nichols GM, Lees MH, Henken DP, Sunderland CO, Starr A. Aortico-left ventricular tunnel: recognition and repair in infancy. Chest (1976) 70:74-7. doi:10.1378/chest.70.1.74

32. Okoroma EO, Perry LW, Scott LP, McClenathan JE. Aortico-left ventricular tunnel: clinical profile, diagnostic features, and surgical considerations. J Thorac Cardiovasc Surg (1976) 71:238-43.

33. Spooner EW, Dunn JM, Behrendt DM. Aortico-left ventricular tunnel and sinus of Valsalva aneurysm: case report with operative repair. J Thorac Cardiovasc Surg (1978) 75:232-6.

34. Björk VO, Eklöf O, Wallgren G, Zetterqvist P. Successful surgical treatment of an aortico-left ventricular tunnel in a four-month-old infant. J Thorac Cardiovasc Surg (1979) 78:35-8.

35. Villani M, Tiraboschi R, Marino A, De Tommasi M, Velitti F, Giani PC, et al. Aortico-left ventricular tunnel in infancy: two surgical cases. Scand J Thorac Cardiovasc Surg (1980) 14:169-75. doi:10.3109/14017438009100993

36. Ruschewski W, de Vivie ER, Kirchhoff PG. Aortico-left ventricular tunnel. J Thorac Cardiovasc Surg (1981) 29:282. doi:10.1055/s-2007-1023496

37. Levy MJ, Schachner A, Blieden LC. Aortico-left ventricular tunnel: collective review. J Thorac Cardiovasc Surg (1982) 84:102.

38. Turley K, Silverman NH, Teitel D, Mavroudis C, Snider R, Rudolph AM. Repair of aortico-left ventricular tunnel in the neonate: surgical, anatomic and echocardiographic considerations. Circulation (1982) 65:1015-20. doi:10.1161/01.CIR.65.5.1015

39. Björk VO, Hongo T, Aberg B, Bjarke B. Surgical repair of aortico-left ventricular tunnel in a 7-day-old child. Scand J Thorac Cardiovasc Surg (1983) 17:185-9. doi:10.3109/14017438309099350

40. Serino W, Andrade JL, Ross DN, de Leval MR, Somerville J. Aorto-left ventricular communication after closure: late postoperative problems. Br Heart J (1983) 49:501-6. doi:10.1136/hrt.49.5.501

41. Ribeiro P, Bun-Tan LB, Oakley CM. Management of aortic left ventricular tunnel. Br Heart J (1985) 54:333-6. doi:10.1136/hrt.54.3.333

42. Meldrum-Hanna W, Schroff R, Ross DN. Aortico-left ventricular tunnel: late follow-up. Ann Thorac Surg (1986) 42:304-6. doi:10.1016/ S0003-4975(10)62740-3

43. Deuvaert FE, Goffin Y, Wellens F, De Paepe J, Primo G. Aortico-left ventricular tunnel (ALVT): a diagnostic and surgical "must". Acta Cardiol (1986) 41: 53-62.

44. Hovaguimian H, Cobanoglu A, Starr A. Aortico-left ventricular tunnel: a clinical review and new surgical classification. Ann Thorac Surg (1988) 45:106-12. doi:10.1016/S0003-4975(10)62413-7

45. Lindberg H, Ovrum E, Bjornstad PG, Stake G, Pedersen T. Surgical repair of aortico-left ventricular tunnel (ALVT). Scand J Thorac Cardiovasc Surg (1988) 22:285-7. doi:10.3109/14017438809106077

46. Warnke H, Bartel J, Blumenthal-Barby C. Aortico-ventricular tunnel. Thorac Cardiovasc Surg (1988) 36:86-8. doi:10.1055/s-2007-1020050

47. Akalin H, Erol C, Oral D, Corapcioglu T, Ucanok K, Ozyurda U, et al. Aorticoleft ventricular tunnel: successful diagnostic and surgical approach to the oldest patient in the literature. J Thorac Cardiovasc Surg (1989) 97:804-5.

48. Hucin B, Horvath P, Skrovanek J, Reich O, Samanek M. Correction of aortico-left ventricular tunnel during the first day of life. Ann Thorac Surg (1989) 47:254-6. doi:10.1016/0003-4975(89)90282-8

49. Duveau D, Baron O, Michaud JL, Lefevre M, Laboux L, Dupon H. Aortico-left ventricular tunnel: long-term follow-up, therapeutic implications. Arch Mal Coeur Vaiss (1989) 82:785-9.

50. Anderson RH. Surgical treatment of aortico-left ventricular tunnel. Eur J Cardiothorac Surg (1991) 5:443-4. doi:10.1016/1010-7940(91)90194-O

51. Horvath P, Balaji S, Skovranek S, Hucin B, de Leval MR, Stark J. Surgical treatment of aortico-left ventricular tunnel. Eur J Cardiothorac Surg (1991) 5:113-6. doi:10.1016/1010-7940(91)90208-2

52. Sreeram N, Franks R, Arnold R, Walsh K. Aortico-left ventricular tunnel: long-term outcome after surgical repair. J Am Coll Cardiol (1991) 17:950-5. doi:10.1016/0735-1097(91)90878-D

53. Rosenkranz ER, Murphy DJ. Aortico-left ventricular tunnel in a neonate. Cleve Clin J Med (1992) 59:87-90. doi:10.3949/ccjm.59.1.87
54. Zannini L, Gargiulo G, Albanese SB, Bonvicini M, Santorelli MC, Frascaroli G, et al. Successful surgical repair of an aortico-left ventricular tunnel in a two-day old child. J Cardiovasc Surg (1992) 33:295-7.

55. Rosengart TK, Redel DA, Stark JF. Surgical repair of aorto-right ventricular tunnel in an infant. Ann Thorac Surg (1993) 55:520-2. doi:10.1016/ 0003-4975(93)91034-K

56. Chen YF, Chiu CC, Wu JR. Correction of aortico-left ventricular tunnel in a small oriental infant: a brief clinical review. J Cardiovasc Surg (1994) 35:71.

57. Cook AC, Fagg NLK, Ho SY, Groves AMM, Sharland GK, Anderson RH, et al. Echocardiographic-anatomical correlations in aorto-left ventricular tunnel. Br Heart J (1995) 74:443-8. doi:10.1136/hrt.74.4.443

58. Sousa-Uva M, Touchot A, Fermont L, Piot D, Delezoide AL, Serraf A, et al. Aortico-left ventricular tunnel in fetuses and infants. Ann Thorac Surg (1996) 61:1805-10. doi:10.1016/0003-4975(96)00189-0

59. Lukacs L, Richter T, Kadar K. Aortico-left ventricular tunnel: late reoperations. Cardiovasc Surg (1997) 5:439-42. doi:10.1016/S0967-2109(97)00039-2

60. Grünenfelder J, Zünd G, Prêtre R, Schmidli J, Vogt PR, Turina MI. Right coronary artery from aorto-left ventricular tunnel: case report of a new surgical approach. J Thorac Cardiovasc Surg (1998) 116:363-5. doi:10.1016/ S0022-5223(98)70143-6

61. Michielon G, Sorbara C, Casarotto DC. Repair of aortico-left ventricular tunnel originating from the left aortic sinus. Ann Thorac Surg (1998) 65:1780-3. doi:10.1016/S0003-4975(98)00211-2

62. Vargas FJ, Molina A, Martinez JC, Ranzini ME, Vazquez JC. Aortico-right ventricular tunnel. Ann Thorac Surg (1998) 66:1793-5. doi:10.1016/ S0003-4975(98)00927-8

63. Diamant S, Luber JM, Gootman N. Successful repair of aortico-left ventricular tunnel associated with severe aortic stenosis in a newborn. Pediatr Cardiol (1985) 6:171-5. doi:10.1007/BF02336559

64. Guyton RA, Michalik RE, McIntyre AB, Plauth WH, Nugent EW, Hatcher CR, et al. Aortic atresia and aortico-left ventricular tunnel: successful surgical management by Konno aortoventriculoplasty in a neonate. JThorac Cardiovasc Surg (1986) 92:1099-101.

65. Knott-Craig CJ, vander Merwe PL, Kalis NN, Hunter J. Repair of aortico-left ventricular tunnel associated with subpulmonary obstruction. Ann Thorac Surg (1992) 54:557-9. doi:10.1016/0003-4975(92)90455-D

66. Bitar FF, Smith FC, Kavey RE, Kveselis DA, Byrum CJ, Brandt B, et al. Aorticoleft ventricular tunnel with aortic atresia in the newborn. Am Heart J (1993) 126:1480-2. doi:10.1016/0002-8703(93)90553-L

67. Martin Jimenez J, Gonzalez Dieguez CC, Quero Jimenez C, Rico Gomez F, Bermudez Canete R, Quero Jimenez M. Aortico-left ventricular tunnel associated with pulmonary valve stenosis. Rev Esp Cardiol (1996) 49:921-4.

68. Weldner P, Dhillon R, Taylor JF, de Leval MR. An alternative method for repair of aortico-left ventricular tunnel associated with severe aortic stenosis presenting in a newborn. Eur J Cardiothorac Surg (1996) 10:380-2. doi:10.1016/ S1010-7940(96)80098-4

69. Rauzier JM, Bonnet D, Zniber L, Sidi D, Aggoun Y, Acar P, et al. Aorticventricular tunnel with right coronary artery atresia. Arch Mal Coeur Vaiss (1997) 90:725-7.

70. Hruda J, Hazekamp MG, Sobotka-Plojhar MA, Ottenkamp J. Repair of aorto-right ventricular tunnel with pulmonary stenosis and an anomalous origin of the left coronary artery. Eur J Cardiothorac Surg (2002) 21:1123-5. doi:10.1016/S1010-7940(02)00115-X

Conflict of Interest Statement: The authors declare that the research was conducted in the absence of any commercial or financial relationships that could be construed as a potential conflict of interest.

Copyright (c) 2018 Corno, Durairaj and Anderson. This is an open-access article distributed under the terms of the Creative Commons Attribution License (CC BY). The use, distribution or reproduction in other forums is permitted, provided the original author(s) and the copyright owner are credited and that the original publication in this journal is cited, in accordance with accepted academic practice. No use, distribution or reproduction is permitted which does not comply with these terms. 